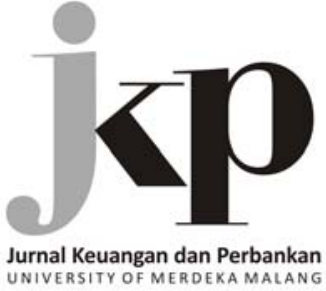

Article history:

Received: 2019-10-17

Revised: 2019-12-12

Accepted: 2020-02-28

Keywords:

Banking; Indonesia; Labor force; Regional economic growth

JEL Classification: O16, G21, G28

Kata kunci:

Bank; Angkatan kerja;

Pertumbuhan ekonomi regional;

Indonesia

$\triangle$ Corresponding Author:

Wahyoe Soedarmono:

Tel. +62 2150222234

E-mail:

wahyoe.soedarmono@sampoernauniversity.ac.id

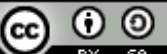

This is an open access

article under the CC-BY-SA license

\section{Banking, labor force, and regional economic growth: Evidence from Indonesia}

\author{
Abd. Rahman Razak ${ }^{1}$, Wahyoe Soedarmono ${ }^{2}$, Wahdi Salasi April Yudhi ${ }^{2}$ \\ ${ }^{1}$ Department of Economics, Faculty of Economics and Business, Hasanuddin University \\ Jl. Perintis Kemerdekaan Km.10, Tamalanrea, Makassar, 90245, Indonesia \\ ${ }^{2}$ Department of Management, Faculty of Business, Sampoerna University \\ L'Avenue Office, Jl. Raya Pasar Minggu Kav.16A, Pancoran, Jakarta, 12780, Indonesia
}

\begin{abstract}
This paper examines whether regional economic growth across Indonesian provinces can be affected by the role of banking and labor force. In general, our empirical findings show that banking development is indeed positively linked to regional economic growth, although this relationship is more pronounced for poor provinces. Moreover, this paper finds that the link between banking development and regional economic growth is conditional on the degree of labor force. Specifically, the positive impact of banking on regional economic growth only occurs when labor force is sufficiently low regardless of whether we observe poor provinces or rich provinces. Eventually, this paper highlights that increasing access to bank credit is essential to boost regional economic growth, especially for poor provinces or provinces with lower labor force.
\end{abstract}

\section{Abstrak}

Penelitian ini menganalisis apakah pertumbuhan ekonomi regional pada tingkat provinsi di Indonesia dapat dipengaruhi oleh peran perbankan dan angkatan kerja. Secara umum, hasil empiris menunjukkan bahwa perkembangan sektor perbankan berhubungan positif terhadap pertumbuhan ekonomi regional, meskipun hubungan ini akan lebih kuat pada provinsi-provinsi dengan tingkat pendapatan penduduk yang rendah. Penelitian ini juga menyimpulkan bahwa hubungan antara perkembangan sektor perbankan dan pertumbuhan ekonomi regional dipengaruhi juga oleh tingkat angkatan kerja. Secara khusus, dampak positif sektor perbankan terhadap pertumbuhan ekonomi regional hanya terjadi ketika tingkat angkatan kerja cenderung lemah, baik di provinsi-provinsi dengan tingkat pendapatan penduduk yang tinggi atau rendah. Pada akhirnya, penelitian ini menyimpulkan bahwa peningkatan akses terhadap kredit perbankan berperan esensial untuk mendorong pertumbuhan ekonomi regional, khususnya di provinsiprovinsi dengan tingkat pendapatan penduduk yang rendah atau provinsi-provinsi dengan tingkat angkatan kerja yang rendah.

How to Cite: Razak, A. R., Soedarmono, W., Yudhi, W. S. A. (2020). Banking, labor force, and regional economic growth: Evidence from Indonesia. Jurnal Keuangan dan Perbankan, 24(2), 156-163. https://doi.org/10.26905/jkdp.v24i2.3533 


\section{Banking, labor force and regional economic growth: Evidence from Indonesia}

Abd. Rahman Razak, Wahyoe Soedarmono, Wahdi Salasi April Yudhi

\section{Introduction}

Since the 1990s, academic literature on the finance-growth nexus has emerged with the notion that the presence of financial intermediary is important to boost long-term investment instead of short-term and speculative ventures and hence, the economy with bank-based system exhibits a higher level of steady-state capital stock in the long run than the economy with financial autarky (Bencivenga \& Smith, 1991; Augier \& Soedarmono, 2010). This notion is empirically proven by King \& Levine (1993) and Rajan \& Zingales (1998) using a cross-country analysis. Following these studies, Fisman \& Love (2002) also examine the positive relationship between finance and growth at the industry level, while Demirguc-Kunt \& Maksimovic (2002) find identical results using a firm-level study. Recently, Soedarmono, Trinugroho, \& Sergi (2019) integrate province-level and firm-level datasets in the Indonesian context in which firms located in provinces with greater financial deepening exhibit higher performance.

Nowadays, the finance-growth nexus literature has acknowledged the fact that greater financial development is not necessarily associated with stronger economic growth regardless of whether country-level, firm-level, and regional-level datasets are used. A new avenue of research in the financegrowth nexus highlights that "too much finance" can adversely impact economic growth (Arcand, Berkes, \& Panizza, 2012; Samargandi, Fidrmuc, \& Ghosh, 2015). Such literature shows that financial development has an inverted U-shaped relationship with economic growth. Soedarmono, Hasan, \& Arsyad (2017) also show an inverted U-shaped relationship between finance and growth in the case of Indonesia in which higher consumption and investment credit can boost regional economic growth before both types of credit reaches a certain level.

In parallel, a non-linear impact of finance on economic growth can also be seen from the existence of thresholds or conditioning factors before financial development enhances economic growth. For instance, greater financial development can only boost economic growth in countries with high per capita income (Rioja \& Valev, 2004a). Identically, Rioja \& Valev (2004b) also find that the positive association between finance and growth can be determined by the degree of financial development itself. Specifically, only countries with greater financial development exhibit a positive link between finance and growth. Beck et al. (2014) also find that the positive link between finance and growth depends on financial cycles and non-intermediation activities of banking. For a single-country setting, it is also shown by Crouzille, Nys, \& Sauviat (2012) that greater rural bank development in the Philippines cannot spur regional economic growth unless the regions already have a certain level of per capita income. Another strand of research also highlights that financial constraints may explain as to why financial development promotes economic growth by reducing firm dependence on internal funding. Specifically, higher levels of financial depth indeed enable firms with higher financial constraints to increase investment and hence, supporting economic growth as a whole (Soedarmono et al., 2019).

In this paper, we extend the finance-growth nexus literature by considering the role of the labor force. In general, slower labor force growth is associated with higher capital per worker, which will increase output growth per worker (Solow, 1956; Swan, 1956). Meanwhile, the role of the labor force is closely related to the role of population in economic development, although previous studies exbibit mixed results regarding the impact of population on economic growth, which depends on the measurement of the population that drives aggregate productivity. For instance, Bloom, Canning, \& Malaney (2000) find a negative impact of total population growth on economic growth, while higher working-age population growth is associated with stronger economic growth. This notion is referred to as the "Harvard" concept. Meanwhile, Golley \& 


\section{Jurnal Keuangan dan Perbankan}

Volume 24, Issue 2, April 2020: 156-163

Wei (2015) document a negative link between the working-age population and economic growth in China. In spite of a debate on the role of demographic variables in economic growth, Tsani et al. (2013) provide evidence that higher labor force participation is indeed beneficial for economic growth, although they focus on the measure of female labor participation.

This paper is not focused on assessing the influence of various demographic factors on economic growth. Instead, we investigate whether the financegrowth nexus is affected by the labor force by building on the work of Tsani et al. (2013). To our knowledge, no previous studies consider whether the labor force can be a threshold in the nexus between financial development and economic growth. As further contribution, the link between financial development, labor force, and regional economic growth is also assessed for rich provinces and poor provinces separately, because previous studies suggest that the finance-growth nexus indeed depends on the degree of economic development (Crouzille et al., 2012; Rioja \& Valev, 2004a).

In order to tackle these issues, we focus on the Indonesian context for some reason. In the aftermath of the 1997 Asian crisis, the Indonesian banking system is characterized by high net interest margins compared to other Asian countries, suggesting that challenges for financial intermediation are substantial in Indonesia (Trinugroho, Agusman, \& Tarazi, 2014). Soedarmono et al. (2017) also show that the degree of financial depth measured by the ratio of credit to gross domestic product (GDP) for Indonesia is the lowest in ASEAN-5 countries from 2000 to 2011 and hence, access to bank credit also remains a challenge for Indonesia. These conditions suggest assessing the link between banking and economic growth for Indonesia is a relevant public policy issue, in order to provide an empirical benchmark for other emerging markets with a bank-based financial system. Yet, World Bank (2014) points out that Indonesia is still reaping the demographic divi- dend until 2030 that will become an engine of longrun economic growth. Hence, the results from Indonesia as a country with the fourth-biggest population in the world can be a lesson for other developing countries whether finance, labor force, and economic growth are interrelated.

The rest of this paper is organized in the following order. Section 2 presents the dataset and research methodology, while Section 3 provides an explanation of the empirical results. Finally, Section 4 provides a conclusion.

\section{Data, Method, and Analysis}

Building on the work of Soedarmono et al. (2017), this paper uses province-level data from 2000 to 2010 retrieved from Central Bank of Indonesia (Bank Indonesia) and the Indonesian Central Statistical Agency (or BPS/Badan Pusat Statistik). There are 33 provinces considered in this study. In order to assess the impact of financial development on regional economic growth at the province level, this paper uses several variables. Firstly, the growth rate of real per capita gross regional domestic product (GRDP) at the province level (GROWTH) is chosen as a dependent variable. Secondly, the ratio of commercial banks' loans to deposits (LDR) is selected to measure the degree of financial development from the perspective of financial intermediation. Higher $L D R$ means that commercial banks at the province level generally engage in greater financial intermediation activities. A set of control variables that can affect regional economic growth are also considered. These include the initial GRDP per capita (GDPC00) following Hasan, Wachtel, \& Zhou (2009), the ratio of net enrolment rate to secondary high school (NER), the ratio of labor force to total population at the province level (LFORCE), and the logarithm of population density at the province level (LNDENSITY). All these control variables are expected to positively influence regional economic growth. 


\section{Banking, labor force and regional economic growth: Evidence from Indonesia \\ Abd. Rahman Razak, Wahyoe Soedarmono, Wahdi Salasi April Yudhi}

Regarding our econometric methodology, the link between financial development and regional economic growth is estimated in three stages. In the first stage, GROWTH is regressed on $L D R$ and control variables for all provinces. The second stage repeats the first stage, but we run regressions for two distinct sub-samples of rich provinces and poor provinces. We group provinces as rich (poor) provinces when per capita real GRDP is higher (or lower) than its median for all provinces. In the third stage, the estimation is carried out to repeat the first and second stages, but we incorporate the interaction term between $L D R$ and $L F O R C E$ to assess whether the link between financial intermediation and regional economic growth is conditional on labor force. Concerning our econometric procedure to estimate the aforementioned models, a random effect panel data model is used, because the regression model contains a time-invariant variable (GDPC00). Hence, a fixed effect panel data model cannot be used, because there is a time-invariant independent variable (GDPC00). In order to ensure robustness, we replace $L D R$ with a financial depth variable (CRED) measured by the ratio of bank credit to GRDP. Higher CRED means that provinces exhibit greater financial development.

\section{Results}

Table 1 shows the descriptive statistics and correlation matrix of all variables considered in this paper. From Table 2, it can be seen that multicollinearity is not a potential problem, as all independent variables are less likely to correlate.

In Table 3, the link between financial intermediation measured by $L D R$ and regional economic growth (GROWTH) is assessed. It is shown that higher financial intermediation undertaken by the banking industry indeed strengthens regional economic growth at the 1 percent level. This result supports the notion that finance leads growth (King \& Levine, 1993; Soedarmono et al., 2017; Soedarmono et al., 2019). A deeper analysis however uncovers that such finding only occurs in poor provinces, suggesting that greater access to finance for poor provinces is important to boost economic growth and

Table 1. Descriptive statistics

\begin{tabular}{|c|c|c|c|c|c|}
\hline Variables & Mean & Maximum & Minimum & Std. Dev. & Observations \\
\hline GROWTH & 0.0353 & 0.2984 & -0.2632 & 0.0386 & 330 \\
\hline GDPCO0 & 5.9782 & 27.0995 & 1.7531 & 5.1055 & 429 \\
\hline$L D R$ & 0.5562 & 1.3987 & 0.1094 & 0.2268 & 330 \\
\hline NER & 0.4276 & 0.6458 & 0.1962 & 0.0943 & 334 \\
\hline LFORCE & 0.4617 & 0.6473 & 0.0729 & 0.0583 & 330 \\
\hline LNDENSITY & 4.5218 & 7.0880 & 1.6981 & 1.3981 & 320 \\
\hline
\end{tabular}

Table 2. Correlation matrix

\begin{tabular}{|c|c|c|c|c|c|c|}
\hline Variables & GROWTH & GDPC00 & $L D R$ & NER & LFORCE & LNDENSITY \\
\hline GROWTH & 1.0000 & & & & & \\
\hline GDPCOO & -0.0902 & 1.0000 & & & & \\
\hline$L D R$ & 0.2148 & -0.1209 & 1.0000 & & & \\
\hline NER & 0.0703 & 0.2860 & 0.0608 & 1.0000 & & \\
\hline LFORCE & 0.1972 & -0.2202 & 0.1167 & 0.0344 & 1.0000 & \\
\hline LNDENSITY & 0.0505 & -0.1222 & 0.2764 & 0.2039 & 0.3167 & 1.0000 \\
\hline
\end{tabular}


prosperity. This result does not support a threshold effect hypothesis stating that the positive link between finance and growth can occur in high-income regions instead of low-income regions (Crouzille et al., 2012).

Meanwhile, Table 4 presents the empirical results when labor force (LFORCE) is considered as a moderating variable that may affect the link between financial intermediation (LDR) and regional economic growth (GROWTH). The findings show that the finance-growth nexus is indeed affected by labor force. Specifically, higher financial intermediation $(L D R)$ can boost regional economic growth
(GROWTH) when labor force at the province level is less than a certain level. This finding remains consistent in both poor provinces and rich provinces. This suggests that the role of financial intermediation is more important in provinces with lower labor force.

For robustness checks, the regression models are modified. Firstly, the explanatory variable of interest $(L D R)$ is replaced by a financial depth variable measured by the ratio of bank credit to total nominal gross regional domestic product (CRED). Table 5 and Table 6 document our empirical results for this modification and the results are consistent.

Table 3. Baseline regression on the finance-growth nexus

\begin{tabular}{|c|c|c|c|c|c|c|}
\hline \multirow{3}{*}{ Explanatory variables } & \multicolumn{6}{|c|}{ Dependent variable: GROWTH } \\
\hline & \multicolumn{2}{|c|}{ All provinces } & \multicolumn{2}{|c|}{ Rich provinces } & \multicolumn{2}{|c|}{ Poor provinces } \\
\hline & Coeff. & t-Stat. & Coeff. & t-Stat. & Coeff. & t-Stat. \\
\hline GDPCO0 & $-0.001367^{*}$ & -1.688030 & -0.002101 & -1.283062 & 0.00016 & 0.072150 \\
\hline$L D R$ & $0.035545^{\star * *}$ & 3.208910 & 0.032249 & 1.019158 & $0.034789^{* * *}$ & 4.559082 \\
\hline NER & 0.040136 & 1.509849 & 0.073210 & 1.030893 & 0.012995 & 0.655692 \\
\hline LFORCE & $0.184161^{* * *}$ & 3.341020 & $0.260016^{* *}$ & 2.292695 & 0.067621 & 1.176526 \\
\hline LNDENSITY & $-0.004843^{* *}$ & -2.421085 & $-0.006491^{*}$ & -1.817777 & -0.000914 & -0.398639 \\
\hline $\mathrm{C}$ & -0.058093 & -2.135724 & -0.089732 & -1.509647 & -0.017283 & -0.766638 \\
\hline R-squared & 0.093 & & 0.097 & & 0.146 & \\
\hline Observation & 268 & & 125 & & 143 & \\
\hline Number of province & 32 & & 15 & & 17 & \\
\hline
\end{tabular}

Notes: Author's calculation. The regression is carried out using a random effect model. *** indicates significance at the 1 percent level, while ** and * indicate significance at the 5 percent and 10 percent levels, respectively.

Table 4. Financial intermediation, labor force, and regional economic growth

\begin{tabular}{|c|c|c|c|c|c|c|}
\hline \multirow{3}{*}{ Explanatory variables } & \multicolumn{6}{|c|}{ Dependent variable: GROWTH } \\
\hline & \multicolumn{2}{|c|}{ All provinces } & \multicolumn{2}{|c|}{ Rich provinces } & \multicolumn{2}{|c|}{ Poor provinces } \\
\hline & Coeff. & t-Stat. & Coeff. & t-Stat. & Coeff. & t-Stat. \\
\hline GDPCO0 & -0.001410 & -1.231403 & -0.002146 & -1.482757 & -0.000362 & -0.159693 \\
\hline$L D R$ & $0.491503^{* * *}$ & 3.086267 & $1.040021^{* * *}$ & 3.992884 & $0.142106^{* * *}$ & 1.601719 \\
\hline LDR $x$ LFORCE & $-0.999999 * * *$ & -2.919662 & $-2.216651^{* * *}$ & -3.899292 & $-0.233911^{* * *}$ & -1.214123 \\
\hline NER & $0.054293^{*}$ & 1.924229 & 0.059206 & 0.960242 & 0.021206 & 1.010291 \\
\hline LFORCE & $0.703308^{* * *}$ & 3.637484 & $1.326431^{* * *}$ & 4.417569 & 0.206694 & 1.611973 \\
\hline LNDENSITY & $-0.005338^{* * *}$ & -2.770560 & $-0.006751^{* *}$ & -2.203558 & -0.001469 & -0.626751 \\
\hline $\mathrm{C}$ & $-0.297062^{* * *}$ & -3.278289 & $-0.564162^{* * *}$ & -4.122079 & -0.080082 & -1.418718 \\
\hline R-squared & 0.143 & & 0.200 & & 0.155 & \\
\hline Observation & 268 & & 125 & & 143 & \\
\hline Number of province & 32 & & 15 & & 17 & \\
\hline
\end{tabular}

Notes: Author's calculation. The regression is carried out using a random effect model. *** indicates significance at the 1 percent level, while ** and * indicate significance at the 5 percent and 10 percent levels, respectively. 


\section{Banking, labor force and regional economic growth: Evidence from Indonesia}

Abd. Rahman Razak, Wahyoe Soedarmono, Wahdi Salasi April Yudhi

Secondly, LNDENSITY is eliminated from the model, but the previous findings are also consistent. The second robustness check is not presented in this paper, but are available upon request.

\section{Conclusion}

This paper extends the finance-growth nexus literature in a single-country setting by differentiating provinces into poor provinces and rich provinces, and by incorporating whether labor force plays a significant role in influencing the finance- growth nexus. The empirical results from a panel dataset of 33 provinces in Indonesia reveal that banking plays an important role in boosting regional economic growth, although this finding is more ponounced for poor provinces. In the next turn, we provide further evidence that the positive effect of financial measured by either financial intermediation or financial depth indicators on regional economic growth is more pronounced for provinces with lower labor force regardless of whether we observe poor provinces or rich provinces. Accordingly, our findings advocate the importance of bank-

Table 5. Robustness check: Financial depth and regional economic growth

\begin{tabular}{lcrrrr}
\hline \multirow{2}{*}{ Explanatory variables } & \multicolumn{3}{c}{ Dependent variable: GROWTH } \\
\cline { 2 - 6 } & \multicolumn{2}{c}{ All provinces } & \multicolumn{2}{c}{ Rich provinces } & Poor provinces \\
\cline { 2 - 6 } & \multicolumn{1}{c}{ Coeff. } & t-Stat. & Coeff. & t-Stat. & Coeff. \\
\hline GDPC00 & -0.001458 & -1.140408 & $-0.002504^{*}$ & -1.730448 & $5.97 \mathrm{E}-05$ \\
CRED & $0.056805^{*}$ & 1.780604 & -0.048429 & -0.553234 & 0.022862 \\
NER & 0.031126 & 1.209214 & 0.128239 & 1.579823 & -0.005561 \\
LFORCE & $0.19062^{* *}$ & 2.312876 & $0.271247^{*}$ & 1.879608 & -0.163475 \\
LNDENSITY & -0.004114 & -1.499772 & -0.004921 & -1.371880 & -0.098998 \\
C & -0.049253 & -1.594713 & -0.097377 & -1.697075 & -0.000363 \\
R-squared & 0.066438 & & 0.091416 & & -0.107778065 \\
Observation & 268 & & 125 & -0.397922 \\
Number of province & 32 & & 15 & & 0.057462 \\
\hline
\end{tabular}

Source and notes: Author's calculation. The regression is carried out using a random effect model. *** indicates significance at the 1 percent level, while ** and * indicate significance at the 5 percent and 10 percent levels, respectively.

Table 6. Robustness check: Financial depth, labor force, and regional economic growth

\begin{tabular}{|c|c|c|c|c|c|c|}
\hline \multirow{3}{*}{ Explanatory variables } & \multicolumn{6}{|c|}{ Dependent variable: GROWTH } \\
\hline & \multicolumn{2}{|c|}{ All provinces } & \multicolumn{2}{|c|}{ Rich provinces } & \multicolumn{2}{|c|}{ Poor provinces } \\
\hline & Coeff. & t-Stat & Coeff. & t-Stat & Coeff & t-Stat \\
\hline GDPCO0 & -0.000595 & -0.581385 & $-0.002005^{*}$ & -1.776139 & 0.000134 & 0.046614 \\
\hline CRED & $1.508701^{* * *}$ & 2.606771 & $2.547785^{\star * *}$ & 3.405898 & $0.413305^{*}$ & 1.396398 \\
\hline CRED $x$ LFORCE & $-3.208646^{* *}$ & -2.577428 & $-5.479539 * * *$ & -3.496911 & $-0.758356^{*}$ & -1.144975 \\
\hline$N E R$ & 0.046929 & 1.616651 & $0.125472^{*}$ & 1.955525 & -0.000355 & -0.014108 \\
\hline LFORCE & $0.772588^{* * *}$ & 3.219142 & $1.193441^{* * *}$ & 4.370760 & $0.242439 *$ & 1.726281 \\
\hline LNDENSITY & -0.002370 & -1.084152 & -0.004113 & -1.500944 & $-5.01 \mathrm{E}-05$ & -0.017458 \\
\hline C & -0.331074 & -2.732516 & -0.532606 & -3.481466 & -0.087280 & -1.355664 \\
\hline R-squared & 0.135606 & & 0.227860 & & 0.066262 & \\
\hline Observation & 268 & & 125 & & 143 & \\
\hline Number of province & 32 & & 15 & & 17 & \\
\hline
\end{tabular}

Source and notes: Author's calculation. The regression is carried out using a random effect model. ${ }^{* * *}$ indicates significance at the 1 percent level, while ** and * indicate significance at the 5 percent and 10 percent levels, respectively. 
ing in provinces with lower labor force. On the contrary, boosting banking development is not sufficient to ensure higher economic growth, particularly in provinces with higher labor force.

Eventually, future research may embrace the issues of non-linearity in the finance-growth nexus as in Soedarmono et al. (2017). Specifically, whether or not the non-linearity exists for different types of provinces with different degree of population is worth investigating to provide insights whether the "threshold" hypothesis and the "too much finance" hypothesis may exist simultaneously. In addition, future research can also distinguish with more recent data whether different types of credit will affect regional economic growth differently for provinces of different population sizes.

\section{References}

Arcand, J., Berkes, E., \& Panizza, U. (2012). Too much finance? IMF Research Department.

Augier, L., \& Soedarmono, W. (2010) Threshold effect, financial intermediation, and macroeconomic performance. 18th Symposium of Society for Nonlinear Dynamics and Econometrics. University of Piemonte Orientale, Italy. http://dx.doi.org/10.2139/ssrn.1611756

Beck, T., \& Degryse, H., de Haas, R., \& van Horen, N. (2014). When arm's length is too far. Relationship banking over the business cycle. BOFIT Discussion Papers 14/2014. Bank of Finland, Institute for Economies in Transition. https://doi.org/10.2139/ssrn.2489017

Bencivenga, V. R., \& Smith, B. D. (1991). Financial intermediation and endogenous growth. Review of Economic Studies, 58(2), 195-209. https://doi.org/10.2307/2297964

Bloom, D. E., Canning, D., \& Malaney, P. N. (2000). Population dynamics and economic growth in Asia. Population and Development Review, 26, 257-290.

Crouzille, M.C., Nys, E., \& Sauviat, A. (2012). Contribution of rural banks to regional economic development: Evidence from the Philippines. Regional Studies, 46(6), 775-791.

https://doi.org/10.1080/00343404.2010.529117

Demirguc-Kunt, A. \& Maksimovic, V. (2002). Funding growth in bank-based and market-based financial system: Evidence from firm-level data. Journal of Financial Economics, 65(3), 337-363. https://doi.org/10.1016/s0304-405x(02)00145-9

Fisman, R. \& Love, I. (2002). Pattern of industrial development revisited: The role of finance. Policy Research Working Paper No.2877. Washington D.C.: World Bank. https://doi.org/10.1596/1813-9450-2877

Golley, J., \& Wei, Z. (2015). Population dynamics and ecoonomic growth in China. China Economic Review, 35, 15-32. https://doi.org/10.1016/j.chieco.2015.05.005

Hasan, I., Wachtel, P. \& Zhou, M. (2009). Institutional development, financial deepening, and economic growth: Evidence from China. Journal of Banking and Finance, 33(1), 157-170. https://doi.org/10.1016/j.jbankfin.2007.11.016

King, R. G., \& Levine, R. (1993). Finance and growth: Schumpeter might be right. Quarterly Journal of Economics, 108(3), 717-737. https://doi.org/10.2307/2118406 


\section{Banking, labor force and regional economic growth: Evidence from Indonesia}

Abd. Rahman Razak, Wahyoe Soedarmono, Wahdi Salasi April Yudhi

Rajan, R. G., \& Zingales, L. (1998). Financial dependence and growth. American Economic Review, 88, 559586. https://doi.org/10.3386/w5758

Rioja F., \& Valev, N. (2004a). Finance and the source of growth at various stages of economic development. Economic Inquiry, 42(1), 127-140. https://doi.org/10.1093/ei/cbh049

Rioja, F., \& Valev, N. (2004b). Does one size fit all? A reexamination of the finance and growth relationship. Journal of Development Economics, 74(2), 429-447. https://doi.org/10.1016/j.jdeveco.2003.06.006

Samargandi, N., Fidrmuc, J., \& Ghosh, S. (2015). Is the relationship between financial development and economic growth monotonic? Evidence from a sample of middle income countries. World Development, 68, 66-81. https://doi.org/10.1016/j.worlddev.2014.11.010

Soedarmono, W., Trinugroho, I., \& Sergi, B. S. (2019). Thresholds in the nexus between financial deepening and firm performance: Evidence from Indonesia. Global Finance Journal, 40, 1-12. https://doi.org/10.1016/j.gfj.2018.08.001

Soedarmono, W., Hasan I., \& Arsyad, N. (2017). Non-linearity in the finance-growth nexus: Evidence from Indonesia. International Economics, 150, 19-35. https://doi.org/10.1016/j.inteco.2016.11.003

Solow, R. M. (1956). A contribution to the theory of economic growth. Quarterly Journal of Economics, 70(1), 65-94. https://doi.org/10.2307/1884513

Swan, T. W. (1956). Economic growth and capital accumulation. Economic Record, 32(2), 334-361. https://doi.org/10.1111/j.1475-4932.1956.tb00434.x

Trinugroho, I., Agusman, A. \& Tarazi, A. (2014). Why have bank interest margins been so high in Indonesia since the 1997/1998 financial crisis? Research in International Business and Finance, 32, 139-58. https://doi.org/10.1016/j.ribaf.2014.04.001

Tsani, S., Paroussos, L., Fragiadakis, C., \& Charalambidis, I. (2013). Female labor participation and economic growth in the South Mediteranian countries. Economics Letters, 120(2), 323-328. https://doi.org/10.1016/j.econlet.2013.04.043

World Bank (2014). Indonesia: Avoiding the trap. Development Policy Review. World Bank Office Indonesia. 